\title{
Correction: Bi-allelic loss of function variants in SLC30A5 as cause of perinatal lethal cardiomyopathy
}

\author{
Johann Kaspar Lieberwirth (D) - Pascal Joset - Anja Heinze • Julia Hentschel • Anja Stein • Antonella lannaccone • \\ Katharina Steindl · Alma Kuechler · Rami Abou Jamra (1)
}

Published online: 9 March 2021

(c) The Author(s), under exclusive licence to European Society of Human Genetics 2021. This article is published with open access

\section{Correction to: European Journal of Human Genetics} https://doi.org/10.1038/s41431-020-00803-8

Following publication of this article, the authors informed the publisher that Alma Kuechler and Rami Abou Jamra contributed equally to this work. This has now been corrected in both the PDF and HTML versions of this article.

Open Access This article is licensed under a Creative Commons Attribution 4.0 International License, which permits use, sharing, adaptation, distribution and reproduction in any medium or format, as long as you give appropriate credit to the original author(s) and the source, provide a link to the Creative Commons license, and indicate if changes were made. The images or other third party material in this article are included in the article's Creative Commons license, unless indicated otherwise in a credit line to the material. If material is not included in the article's Creative Commons license and your intended use is not permitted by statutory regulation or exceeds the permitted use, you will need to obtain permission directly from the copyright holder. To view a copy of this license, visit http://creativecommons. org/licenses/by/4.0/. 